remains accessible. It should be emphasized that large discrepancies will occur during preliminary comparisons between foliage and thermograph if conditions of exposure are not uniform. A surprisingly small amount of shade, which may not be obvious during casual inspection, will produce differences of $2-3^{\circ}$. Also, exposure to winds should be uniform during the tests.

There is no reason why paints with different absorption bands should not be tested. Moreover, in tests related to broad-leaved plants, it might be advisable to wrap a portion of the bimetal in a moist wick to simulate the effects of transpiration. Actually, the leaves of certain field crops appear to be long enough, so that living leaves might be wrapped around a suitably placed bimetal. Other modifications of existing equipment will occur to the reader interested in obtaining more representative temperature measurements.

${ }^{1}$ Curtis, O. F., Plant Physiol., 11, 343 (1936).

'Curtis, O. F., ibid., 595.

'Curtis, O. F., Amer. J. Bot., 25, 761 (1938).

- Gunn, D. L., Biol. Rev., 17, 293 (1942).

'Uvarov, B. P., Trans. Roy. Ent. Soc. Lond., 99, 1 (1948).

' Kirkpatrick, T. W., Amani Memoirs, 1 (London, 1935).

'Wellington, W. G., Canad. Ent. (in the press).

\section{STATE SUPPORT IN SWEDEN FOR SCIENTIFIC PUBLICATIONS}

\section{By Dr. GÖSTA W. FUNKE}

\section{Secretary, Swedish Natural Science Research Council}

For R several years sciece in all civilized countries has enjoyed consi orable Government interestan interest which /as, among other things, found expression in the placing at its disposal of considerable sums of money fr apparatus, buildings, salaries, etc. On the other hand, very little seems as yet to have been done facilitate the publication of the everincreasing flow of the results of the research which has engled as a consequence of improved conditions for solentific investigation. It is self-evident that facilities for publication must be expanded to keep pace with the expansion in scientific activity if the latter is to be fully utilized. That this fact is appreciated may be seen from the Royal Society Scientific Information Conference held last summer in London. At this Conference several speakers emphasized the necessity for Government measures to support publication, so as to complete the official steps which had already been taken for the benefit of science. Since Sweden has, by decision of the 1947 Riksdag, voted a grant for the publication of the results of scientific work, which is large in relation to the country's circumstances, a short summary of this measure may be of interest and provide a stimulus towards similar measures in other countries where there are corresponding requirements.

The grant in question is only intended for the publication of the results of basic research in the field of pure science; but it is hoped shortly to obtain a similar grant for technical and medical research, etc. The grant amounts to 300,000 Swedish crowns (rather more than $£ 20,000$ ) per annum, and is administered by the Swedish Natural Science Research Council. For purposes of comparison, it may be stated that the Council has at its disposal for distri- bution in grants for actual research work the sum of $1,000,000$ Swedish crowns (about $£ 65,000$ ) per annum. The proportion between grants for research and publication is thus approximately in the ratio of three to one, which shows the importance attached to the facilities for publishing the results produced by research.

For the administration of the grant the Council has set up a special Publications Committee, with representatives of scientific research workers, editors of periodicals, libraries, and printing specialists. The greater part of the grant is used to assist periodicals ; but contributions are also made towards text-books and manuals, monographs, etc. A special item is the contribution towards the printing of doctorate theses, of which the expense had formerly, to a large extent, to be borne by the writers of the theses themselves.

It has been possible to start several new periodicals with the help of this grant, as, for example, Acta chemica scandinavica, Tellus (a geophysical periodical), Physiologia plantarum, Oikos (a periodical devoted to ecology), and to expand those already in existence. It is the intention of the Council to support only periodicals of international standing. The new periodicals have therefore generally come into existence with the collaboration of, and financial contributions from, the other Scandinavian countries, Denmark, Finland and Norway. In order to promote their circulation abroad, it is stipulated that articles in those periodicals assisted by the Council shall for the most part be written in English, French or German. The Government grant also enables the Research Council to consider other forms of publication.

\section{FORTHCOMING EVENTS}

(Meetings marked with an asterisk * are open to the public)

\section{Tuesday, April 19}

Society of Chempal INDUSTRY, AGRICUlTURE Group (in the Chemistry Denartme to nperial College of Science and Technology, Imperial Ifífitu' "oad, London, S.W.7), at 2.30 p.m.-Mr. S. J. Wapon: "The Ch mistry of Ensilage".

Tuesday, April 19-Saturday, April 23

South-Eastern Union of ScIentific Societies (at the King's School, Canterbury). - Fifty-third Annual Congress.

Wednesday, April 20

At 8.30 ,p.m.-Mr. F. H. Edmunds: “Geological Surveys and their Intluence" (Presidential Address).

Friday, April 22

At 7.45 p.m. (at the Chapter House).-Young Naturalists' Fvening.

\section{Wednesday, April 20}

Roxal Institute of Chemistry, London and S.E. Counties SECTION (at the London School of Hygiene and Tropical Medicine, Keppel Street, London, W.C.1), at 3 p.m.-Symposium on "Standardisation in the Chemical Field".

Royal Meteorological Society (at 49 Cromwell Road, London, S.W.7), at 5 p.m.-Dr. G. E. R. Deacon, F.R.S.: "W aves and Swell" (Symons Memorial I.ecture).*

ROYAL MIOROSOOPICAL Societr (in the Hastings Hall, B.M.A. House, Tavistock Square, London, W.C.1), at 5.30 p.m.-Prof. J. Gough and Mr. J. E. Wentworth : "The Use of Thin Sections of Entire Organs in Morbid Anatomical Studies"; Mr. F. W. Taylor: "The Phase-Contrast Microscope with particular reference to Vertical Incident Illumination"

\section{Wednesday, April 20-Thursday, April 21}

Societr For GeneraI MIOROBIology (at the Royal Institution, Albemarle Street, London, W.1).

Wednesday, April 20

At 11 a.m. - Symposium on "The Nature of the Bacterial Surface" Thursday, April $2 \mathbf{1}$

At 10 a.m. - Scientific Papers and Demonstrations. 